\title{
Chemical constituents and lethality of Paullinia weinmanniaefolia (Sapindaceae) against Artemia salina Leach
}

\author{
Graziella. P. Claudino, Juliana B. Simões, Ivo J. C. Vieira, Raimundo Braz-Filho, \\ Leda Mathias* \\ Laboratório de Ciências Químicas, Universidade Estadual do Norte Fluminense Darcy Ribeiro, 28013-602 \\ Campos dos Goytacazes-R.J, Brazil
}

\begin{abstract}
RESUMO: "Constituintes químicos e letalidade de Paullinia weinmanniaefolia (Sapindaceae) contra Artemia salina Leach". Os extratos obtidos de folhas e caule de Paullinia weinmmaniaefolia foram testados contra larvas de Artemia salina e mostraram significante letalidade. Os extratos das folhas em diclorometano e do caule em metanol e metanol-água (8:2) apresentaram atividade com valores de $\mathrm{CL}_{50} 366,87 ; 375,38$ e 620,30 ppm, respectivamente. Sete triterpenos, dois esteróides e um ciclitol foram identificados através de técnicas espectrométricas como principais constituintes destes extratos.
\end{abstract}

Unitermos: Paullinia weinmmaniaefolia, Sapindaceae, triterpenos, Artemia salina, letalidade.

\begin{abstract}
The extracts obtained from leaves and steam of Paullinia weinmmaniaefolia were tested against Artemia salina larvae and showed significant lethality. The extracts in dichloromethane of the leaves, in methanol and methanol-water (8:2) of the steam showed activity with $\mathrm{LC}_{50}$ values of 366.87 , 375.38 and $620.30 \mathrm{ppm}$, respectively. Seven triterpenes, two steroids and one cyclitol were characterized by spectrometric methods with majoritary constituents of these extracts.
\end{abstract}

Keywords: Paullinia weinmmaniaefolia, Sapindaceae, triterpenes, Artemia salina, lethality.

\section{INTRODUCTION}

The Sapindaceae family, also know as the Soapberry family, has about 136 genera with 2.000 species (Ferruci, 2000). Sapindaceae includes many species of economically valuable tropical fruit, including the Lychee, the Guarana, the Longan, the Rabumtan, the Manoncilho and the Akee (Menzel et. al., 1998). The Sapindaceae species are trees, shrubs, herbs and lianas occurring in temperate to tropical regions throughout the world. The Paullinia genera comprise about 180 species all Neotropical lianas with the exception of $P$. pinnata occurring also in the African tropics (Henman, 1982). From the species P. cupana and P. pachycarpa were isolated alkaloids (Mattei et al., 1998), (Abourashed et al., 1999) and from P. pinnata were isolated flavones (Weckerle, 2003).

The Artemia salina larvae have been used as target organism to detect bioactive compounds in plant extracts and toxicity to this crustacean has good correlation with anti-tumor (McLaughlin, 1991; Lhullier et al., 2006; Shoeb et al., 2007; Silva et al., 2007; Subhan et al., 2008) and anti Trypanosoma cruzi (Zani, 1995).

P. weinmaniaefolia is a liana native to restinga region, known by the vernacular name of "cipó sangue" (Assunpção \& Nascimento, 2000). There is no previous report in the literature concerning the isolation of the chemical constituents of $P$. weinmmaniaefolia. In this paper, we report the phytochemical study of leaves and steam of a specimen from P. weinmanniaefolia, involving isolation, structural characterization and evaluation of lethality against $A$. salina Leach, including of the crude extracts. The compounds were identified by spectroscopic methods, meanly spectral data obtained by ${ }^{1} \mathrm{H}$ and ${ }^{13} \mathrm{C}$ NMR spectra.

\section{MATERIAL AND METHODS}

\section{Botanical materials}

Leaves and steams of $P$. weinmmaniaefolia Mart. (Sapindaceae) were colleted in February 2003, in the city of São João da Barra, State of Rio de Janeiro, Brazil, in the Lagunar complex Grussaí-Iquipari, was identified by Jorge Assunção and a voucher specimen (No. 238) is deposited in UENF/CBB/LCA Herbarium in the Bioscience e Biotechnology Center, Campos dos Goytacazes, Brazil.

\section{Extracts preparation and larvae evaluation}

The dried and powdered leaves and steams of $P$. weinmmaniaefolia were extracted at room temperature 
successively using hexane, dichloromethane, methanol and methanol-water (8:2). The solvents were removed under vacuum to yield the crude extracts. The crude extracts were tested against $A$. salina larvae as methodology proposed by McLaughlin and collaborators (McLaughlin et al., 1982). The lethal concentration 50\% $\left(\mathrm{LC}_{50}\right.$ value $)$ and the standard error were calculated by Probit analysis (Finney, 1971).

\section{Purification of constituents}

The hexane and dichloromethane extracts were submitted to analytical TLC analysis and chromatographed on a silica gel column eluting with hexane/dichloromethane/methanol mixtures of increasing polarity, to produce the triterpenes (1-8) and the steroids (9-10). The crude methanol extract was acetylated with acetic anhydride in the presence of pyridine and purified on a silica gel column eluting with dichloromethane/ethyl acetate/ methanol mixtures of increasing polarity until isolation of peracetyl cyclitol (11).

Table 1. Results of brine shrimp lethality from extracts of $P$. weinmmaniaefolia.

\begin{tabular}{lll}
\hline Extracts & Material & LC $_{50}(\mathrm{ppm})$ \\
\hline Dichloromethane & Steam & $>1000^{*}$ \\
Methanol & Steam & $375.38 \mathrm{SE} \pm 0.08$ \\
Methanol-water (8:2) & Steam & $620.30 \mathrm{SE} \pm 0.14$ \\
Dichloromethane & Leaf & $365.87 \mathrm{SE} \pm 0.03$ \\
Methanol & Leaf & $>1000^{*}$ \\
Methanol-water (8:2) & Leaf & $>1000^{*}$
\end{tabular}

$* \mathrm{LC}_{50}=$ Lethal Concentration $50 \% \mathrm{SE}=$ Standard error.<smiles>CC1C(=O)CC[C@@]2(C)CC1C1(C)CCC3C4(C)CCC(C(C)(C)CC4)C3(C)CCC12</smiles>

(1)

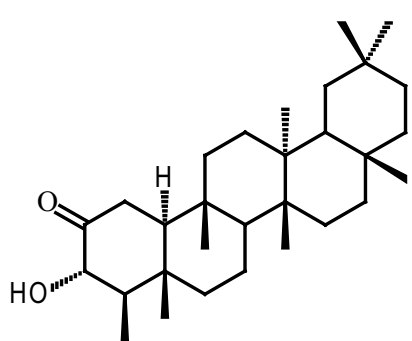

(2)<smiles>CC1C(=O)CC[C@]2(C)C1CCC1(C)C3CCC4(C)CCC(C)(C)CC4C3(C)CCC12CCO</smiles>

(3)

(4)<smiles>C=C(C)C1CCC2(C)CC[C@]3(C)C(CCC4C5CCC(O)C(C)(C)C5CCC43C)C12</smiles>

(5)<smiles>CC1C[C@H](C)C(C)C2C1=CCC1C3CCC4(C)C(C)(C)C(O)CC[C@@]4(C)C3(C)CCC12C</smiles>

(6)
(7)

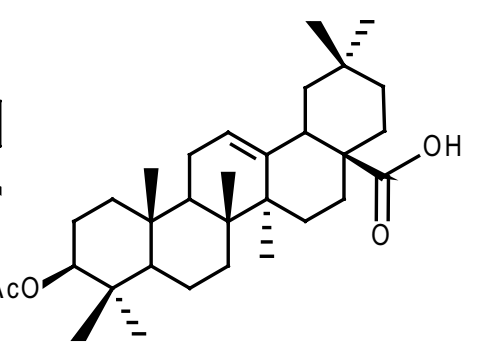

(8)<smiles>CCC(CCC(C)C(C)C)C1CCC2C3CC=C4CC(O)CCC4(C)C3CCC12C</smiles>

(9)<smiles>COC(=O)OC1C(OC)C(OC(C)=O)C(OC(C)=O)C(OC(C)=O)C1OC</smiles>

(11)

Figure 1. Constituents isolated from $P$. weinmanniaefolia. 


\section{RESULTS AND DISCUSSION}

The results of brine shrimp lethality test from extracts of $P$. weinmmaniaefolia are described in Table 1. Among the extracts examined, the dichloromethane of leaves, methanol and methanol-water (8:2) of steam showed activity with $\mathrm{LC}_{50}$ values of 366,375 and 620 ppm, respectively.

The triterpenes friedelin (1), lupeol (5), $\alpha$-amirin (6) and $\beta$-amirin (7) were isolated from leaves and steam; friedelanane (2), canophyllol (3), epifriedelinol (4), 3-O-acetylolean-12-en-28-oic (8) acid; the steroids stigmasterol (9) and $\beta$-sitosterol (10) and the peracetyl derivative of $1,3,4,5,6$-penta- $O$-acetyl2-O-methyl-L-chiro-inositol (11, derivative obtained by treatment with acetic anhydride in the presence of pyridine) were isolated from steam (Figure 1). The compounds were identified by spectroscopic methods, meanly spectral data obtained by ${ }^{1} \mathrm{H}$ and ${ }^{13} \mathrm{C}$ NMR (1D and $2 \mathrm{D}$ experiments) spectra involving comparison with values described in the literature for triterpenoids 1-8 (Ahmad \& Atta-ur-Rahman, 1994) and steroids 9 and 10 (commonly isolated from plants).

\section{ACKNOWLEDGMENTS}

We thank Universidade Estadual do Norte Fluminense (UENF), Fundação de Amparo à Pesquisa do Estado do Rio de Janeiro (FAPERJ), Coordenação e Aperfeiçoamento de Pessoal de Ensino Superior (CAPES) and Conselho Nacional de Desenvolvimento Científico e Tecnológico (CNPq) for fellowships and financial support and the biologist Jorge Assunção, LCA - Centro de Biociência e Biotecnologia - UENF, Campos dos Goytacazes, RJ, Brazil for the identification of this plant.

\section{REFERENCES}

Abourashed EA, Toyang NJ, Choinski JJ, Ikhlas AK 1999. Two new flavone glycosides from Paullinia pinnata. J Nat Prod 62: 1179-1181.

Ahmad VU, Atta-ur-Rahman 1994. Handbook of Natural Product Data - Pentacyclic Triterpenoids, vol. 2. Elsevier, Amsterdam.

Assumpção J, Nascimento MT 2000. Estrutura e composição florística de quatro formações vegetais de restinga no complexo lagunar Grussaí/Iquipari, São João da Barra, RJ, Brasil. Acta Bot Bras 14: 301-315.

Ferrucci MS 2000. Cytotaxonomy of Sapindaceae with special reference to the tribe Paullinieae. Genet Mol Biol 23: 941-946.

Finney DJ 1971. Probit Analysis. Cambridge University Press; Cambridge.

Henman AR 1982. Guaraná (Paullinia cupana var. sorbilis): Ecological and social perspectives on an economic plant of the central amazon basin. J Ethnopharmacol 6: 311-338.
Lhullier C, Horta PA, Falkenberg M 2006. Avaliação de extratos de macroalgas bênticas do litoral catarinense utilizando o teste de letalidade para Artemia salina. Rev Bras Farmacogn 16: 158-163.

Mattei R, Dias RF, Espínola EB, Carlini EA, Barros SBM 1998. Guaraná (Paullinia cupana): toxic behavioral effects in laboratory animals and antioxidant activity in vitro. J Ethnopharmacol 60: 111-116.

Mclaughlin JL, Meyer BN, Ferrigni NR, Putnam JE, Jacobsen LB, Nichols DE 1982. Brine shrimp: a convenient general biossay for active plant constituents. Planta Med 45: 31-34.

McLaughlin JM 1991. Crown gall tumors on potato discs and brine shrimp lethality: two simple bioassays for higher plant screening and fractionation. In $\mathrm{K}$ Hostettmann, Assays for Bioactivity, Academic Press; San Diego, p. 2-32.

Menzel C, McConchie C. Lychee and longan 1998. The new Rural Industries: A handbook for farmers and Investors; 288 - 295.

Shoeb M, MacManus SM, Jaspars M, Kong-Thoo-Lin P, Nahar L, Celik S, Sarker SD 2007. Bioactivity of two Turkish endemic Centaurea species, and their major constituents. Rev Bras Farmacogn 17: 155-159.

Silva TMS, Nascimento RJB, Batista MM, Agra MF, Camara CA 2007. Brine shrimp bioassay of some species of Solanum from Northestern Brazil. Rev Bras Farmacogn 17: 35-38.

Subhan N, Alam MA, Ahmed F, Shahid IJ, Nahar L, Sarker SD 2008. Bioactivity of Excoecaria agallocha. Rev Bras Farmacogn 18: 521-526.

Weckerle C, Stutz M, Baumann TW 2003. Purine alkaloids in Paullinia. Phytochemistry 64: 723-742.

Zani CL, Chaves PPG, Queiroz R, Mendes NM, Oliveira AB, Cardoso JE, Anjos AMG, Grandi TS 1995. Brine shrimp lethality assay as a prescreening system for anti-Trypanosoma cruzi activity. Phytomedicine 2: 47-50. 